\title{
Pengaruh Pengungkapan Corporate Social Responsibility Terhadap Nilai Perusahaan BUMN Sektor Pertambangan
}

\author{
Muhlis $^{1}$, Karlina Sari Gultom ${ }^{2}$ \\ ${ }^{12}$ Program Studi Manajemen, STIE Dewantara Bogor-Jawa Barat \\ Email :mmuhlis2013@gmail.com
}

\begin{abstract}
This study was conducted to determine the effect of disclosure of Corporate Social Responsibility $(S C R)$ on the value of state-owned enterprises (BUMN) in the mining sector listed on the Indonesia Stock Exchange. The data used is data from three mining companies in the 2013-2018 period. The reference for CSR disclosure in this study uses the Global Reporting Initiative (GRI) guidelines which consist of 3 indicators, namely economic indicators, environmental indicators and social indicators. The analysis technique of this research use multiple linear regression. The partial test results show that environmental indicators and social indicators have an effect on firm value. Simultaneous test results show that CSR has an influence on firm value. Social indicators are indicators that have the greatest influence on firm value.
\end{abstract}

Keywords: firm value, corporate social responsibility, economic indicators, environmental indicators, social indicators

\begin{abstract}
ABSTRAK
Penelitian ini dilakukan bertujuan untuk mengetahui pengaruh pengungkapan Corporate Social Responsibility (SCR) terhadap nilai perusahaan Badan Usaha Milik Negara (BUMN) pada sektor pertambangan yang terdaftar di Bursa Efek Indonesia. Data yang digunakan adalah data tiga perusahaan pertambangan pada periode 2013-2018. Acuan pengungkapan CSR dalam penelitian ini menggunakan pedoman Global Reporting Initiative (GRI) yang terdiri dari tiga Indikator yaitu indikator ekonomi, indikator lingkungan dan indikator sosial. Teknik analisis dalam penelitian ini menggunakan regresi linear berganda. Hasil pengujian secara parsial menunjukan bawah indikator lingkungan dan indikator sosial yang berpengaruh terhadap nilai perusahaan. Hasil uji secara simultan menunjukkan bahwa CSR memiliki pengaruh terhadap nilai perusahaan. Indikator sosial merupakan indikator yang memiliki pengaruh terbesar terhadap nilai perusahaan.
\end{abstract}

Kata Kunci: nilai perusahaan, corporate social responsibility, indikator ekonomi, indikator lingkungan, indikator sosial

\section{PENDAHULUAN}

Secara umum setiap perusahaan memiliki tujuan utama dalam menjalankan roda perusahaan, dimana tujuan utama sebuah perusahaan adalah mencari keuntungan (profit). Dalam menjalankan bisnis, perusahaan harus menaati semua peraturan hukum yang berlaku di suatu negara, mulai dari aturan perburuhan hingga aturan kelestarian lingkungan. Industri pertambangan merupakan industri yang sangat erat kaitannya dengan pemanfaatan sumber daya alam, sehingga sangat erat kaitannya dengan pelaksanaan CSR. Tanpa menamfikan dampak positifnya, dampak negatif dalam ranah sosial dan lingkungan yang ditimbulkan sektor industri ini sangat luar biasa. Selama ini industri pertambangan dianggap sebagai sumber kerusakan lingkungan, mengeksploitasi sumber daya alam, dan hanya mementingkan keuntungan semata. Kemajuan teknologi informasi sekarang ini menurut Wahjudi dan Sukmasari (2014) memudahkan masyarakat

\section{JIAKES}

Jurnal Ilmiah Akuntansi Kesatuan ol. 9 No. 1, 2021 pg. 191-198
IBI Kesatuan ISSN $2337-7852$ E-ISSN 2721 - 3048 
Firm Value and Corporate Social Responsibility

192 dalam mengakses berbagai informasi dari berbagai penjuru dunia. Jika perusahaan tidak menunjukkan komitmen sosial yang baik di suatu daerah, informasi ini akan cepat tersebar luas ke berbagai penjuru dunia yang akibatnya akan terbentuknya citra yang negatif. Sebaliknya, jika perusahaan menunjukkan komitmen sosial yang tinggi terhadap kegiatan kemanusiaan, pelestarian lingkungan, kesehatan masyarakat, pendidikan, penanggulangan bencana alam, maka akan terbentuk citra positif bagi perusahaan. Salah satu konsep dalam mewujudkan tanggung jawab sosial perusahaan yang perlu dilakukan sebagai komitmen antara pimpinan dan bawahan yang populer dikenal dengan Corporate Social Responsibility (CSR). Keberhasilan CSR sendiri dapat diukur melalui indikator yang disebut dengan corporate social performance. Salah satu konsep dalam mewujudkan tanggung jawab sosial perusahaan yang perlu dilakukan sebagai komitmen antara pimpinan dan bawahan yang populer dikenal dengan CSR. Keberhasilan CSR sendiri dapat diukur melalui indikator yang disebut dengan corporate social performance.

Perusahaan pertambangan merupakan salah satu peusahaan yang bergerak dalam mengelola sumberdaya alam yang dapat mengakibatkan perusakan lingkungan. Perusahaan pertambangan yang ada di Indonesia ada yang dimiliki oleh perusahaan swasta maupun perusahaan BUMN. Beberapa perusahaan tambang yang dimiliki BUMN diantaranya PT Aneka Tambang Tbk, PT Bukit Tambang Tbk dan PT Timah Tbk. Pada Gambar 1 dapat dilihat kondisi nilai peruahaan dari tahun 2013-2019 dengan trend yang menurun. Hal ini dapat disebabkan oleh adanya beberapa faktor yang mempengaruhi naik turunnya nilai perusahaan, salah satunya Corporate Social Responsibility (CSR) atau tanggung jawab sosial perusahaan. Menurut Listiyani (2017) menyebutkan pertambangan salah satu kegiatan pembangunan ekonomi yang mengacu kepada pembanganunan nasional ayang akan meningkatkan kesejahteraan masyarakat, tetapi dalam pelaksanaannya rentan terhadap penceramaran perusakan lingkungan. Kondisi ini mengharuskan pemerintah mengatur dalam proses pertambangan sehingga terjaga hak setiap warga untuk mendapatkan lingkungan yang sehat dan baik.

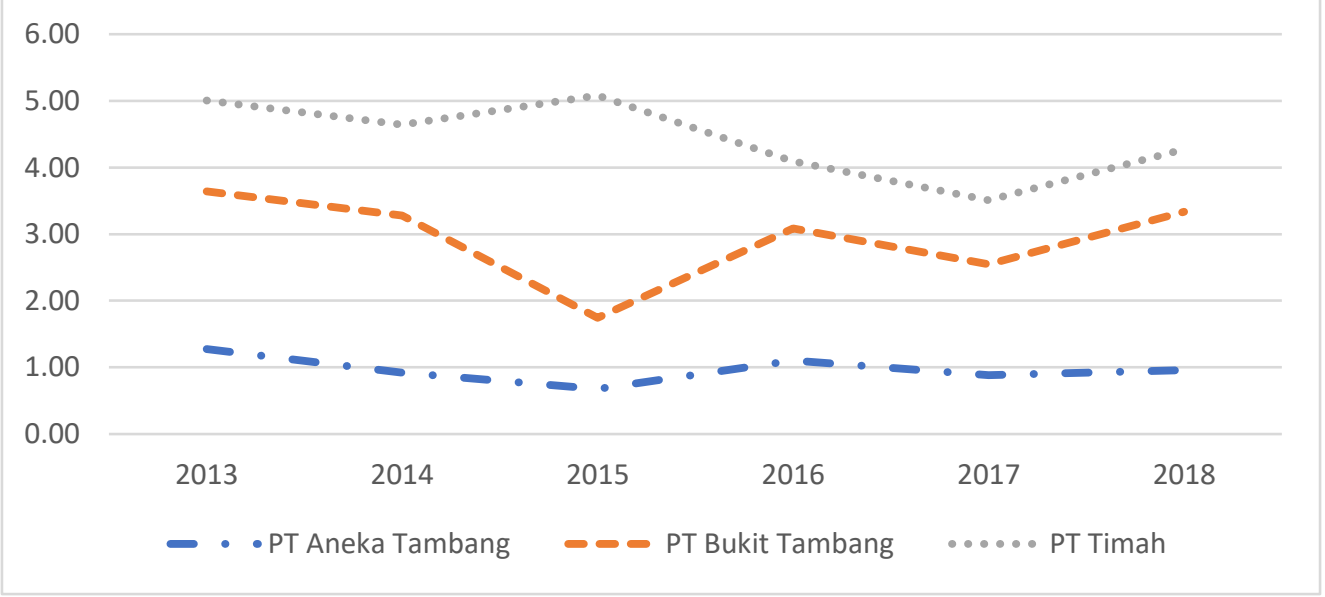

Sumber: Indonesia Stock Exchange (2019)

Gambar 1. Grafik Pertumbuhan Nilai Perusahaan Pertambangan Tahun 2013-2018

Perusahaan pertambangan yang dijadikan objek penelitian hanya perusahaan pertambangan yang berada di bawah naungan BUMN, karena perusahaan-perusahaan tersebut memiliki amanat yang diatur dengan jelas dalam Peraturan Mentri Negara BUMN No. Per-05/MBU/2007 yang menyatakan Program Kemitraan Badan Usaha Milik Negara dengan Usaha Kecil dan Program Bina Lingkungan yang mengharuskan setiap BUMN melakukan penyisihan masing-masing maksimal 3\% dari laba bersih setelah pajak untuk program kemitraan dan bina lingkungan. Berdasarkan uraian diatas maka tujuan penelitian ini untuk mengetahui apakah perusahaan yang tetap menjalankan berkomitmen menjalankan CSR akan berpengaruh terhadap Nilai Perusahaan. Ghoul et al (2011) menyebutkan bahwa semakin tinggi kegiatan CSR yang diungkapkan oleh 
perusahaan akan meningkatkan nilai perusahaan yang ditujukkan oleh peningkatan nilai saham. Peningkatan nilai saham dikarenakan apresiasi positif dari pasar terhadap perusahaan yang melakukan aktivitas CSR. CSR akan mempengaruhi keberlangsungan perusahaan melalui penambahan nilai tambah bagi pemangku kepentingan. (Mc Williams dan Siegel, 2001; Scholtens, 2008). Menurut Sujana (2017) kondisi keuangan perusahaan tidak dapat menjamin keberlanjutan pertumbuhan perusahaan. Kegiatan para pemangku kepentingan perusahaan dalam aktivitas sosial dan lingkungan akan menjamin keberlanjutan perusahaan. Pengungkapan aktivitas CSR oleh perusahaan merupakan media yang informatif bagi pemegang saham yang merupakan bagian dari pemengku kepentingan perusahaan (Walter, 2014; Lii and Lee, 2012). Rustiarini (2010) menyebutkan penyusunan informasi pengungkapan CSR sangat penting bagi peningkatan nilai perusahaan.

Cheng dan Christiawan (2011) menyebutkan bahwa konsep pelaporan pengungkapan CSR yang digagas oleh GRI merupakan konsep sustainablity report. Metode triple bottom line digunakan dalam sustainability report, dimana dalam pelaporan pengungkaan CSR tidak hanya melaporkan perspektif ekonomi tetapi harus juga melaporkan prespektif lingkungan dan sosial. Harga saham yang merupakan indikator dari kinerja manajemen tidak lagi dilihat dari pendapatan laba yang diperoleh, tetapi harus mencapi nilai sosial dan lingkungan sesuai triple cottom line (Elkington, 1997). Sehingga menurut Kamil dan Antonius (2012) CSR merupakan aktivitas yang dilakukan oleh perusahaan untuk mencapai kinerja sosial dan lingkungan.

Nilai perusahaan merupakan indikator nilai pasar saham yang sangat dipengaruhi oleh peluang investasi. Terdapatnya peluang investasi dapat merupakan sinyal positif dari pertumbuhan perusahaan dimasa yang akan datang, kondisi ini akan meningkatkan nilai perusahaan. Tobin's q merupakan indikator yang digunakan untuk mengukur nilai perussahaan yang merupakan bagian kinerja perusahaan. Tobin's q menunjukkan suatu kinerja manajemen dalam mengelola aset perusahaan. Nilai Tobin's q merupakan gambaran suatu peluang kondisi investasi yang dimiliki perusahaan (Lang, et al 1989) atau merupakan potensi pertumbuhan perusahaan (Tobin, 1969).

\section{METODE PENELITIAN}

Variabel penelitian adalah sesuatu hal yang berbentuk apa saja yang ditetapkan oleh peneliti untuk dipelajari sehingga diperoleh informasi tentang hal tersebut, kemudian ditarik kesimpulannya. Berkaitan dengan penelitian ini, variabel penelitian terdiri dari variabel dependen dan variabel independen yang diuraikan sebagai berikut: Variabel dependen adalah variabel yang dipengaruhi oleh variabel bebas. Variabel dependen yang digunakan dalam penelitian ini adalah nilai perusahaan $(\mathrm{Y})$ yang diukur menggunakan proksi rasio Tobin's Q. dan Variabel independen adalah variabel yang memenpengaruhi atau yang menjadi sebab adanya perubahan atau timbulnya variabel dependen. Indikator GRI yang digunakan yaitu: indikator ekonomi (X1) yang dilihat dari 200 indikator, indikator lingkungan (X2) yang dilihat dari 300 indikator dan indikator sosial (X3) yang dilihat dari 400 indikator.

Data yang digunakan dalam penilitian ini adalah data laporan tahunan periode 20132018 perusahaan BUMN pada sektor pertambangan yang masih aktif pada periode 2019. Perusahaan tambang yang terpilih adalah 1) PT Aneka Tambang (Persero)Tbk, 2) PT Bukit Tambang (Persero) Tbk dan 3) PT Timah (Persero)Tbk. Data-data tersebut dianalisis menggunakan regresi liner berganda dengan uji-uji yang dilakukan adalah sebagai berikut: Uji asumsi klasik (uji normalitas, uji hetroskedastisitas, uji multikolineritas dan uji auto kolerasi), Uji regresi linier berganda, Uji hipotesis (uji t dan uji f), Uji determinasi

\section{PEMBAHASAN}

Uji normalitas dalam pengujian ini bertujuan untuk menguji apakah dalam model regresi, variabel penggangu atau residual memiliki distribusi normal. Pengujian ini menggunakan uji Kolmogorov-Smirnov, untuk mengetahui apakah data terdistribusi secara
Firm Value and

Corporate Social Responsibility 
Firm Value and Corporate Social Responsibility

\section{4}

normal atau tidak. Hasil uji normalitas dapat dilihat pada Tabel 1. Hasil uji dapat diketahui nilai signifikan Kolmogorov-Smirnov sebesar 0.200. Nilai Sig tersebut lebih besar dari nilai signifikansi yang telah ditentukan yaitu sebesar 0.05 , maka dapat dikatakan data berdistribusi normal.

Tabel 1. Hasil Uji Normalitas Kolmogorov-Smirnov

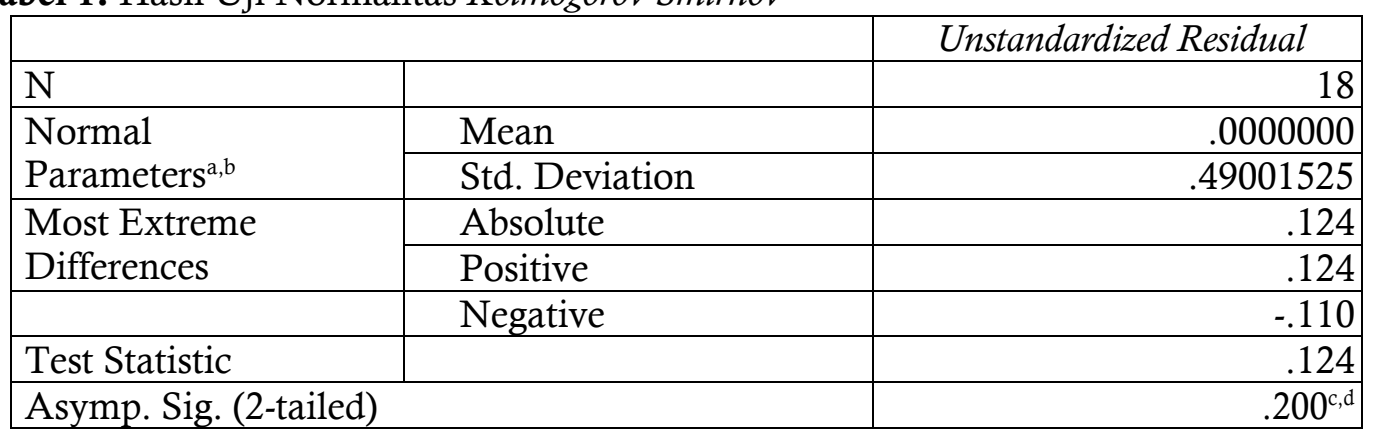

Uji heterokedastisitas bertujuan untuk menguji apakah dalam regresi terjadi ketidaksamaan variance dari residual satu pengamatan ke pengamatan lain. Untuk menguji heterokedastisitas dalam penelitian ini menggunakan metode grafik scatterplot.antara nilai prediksi variabel dependen yaitu ZPRED dengan residualnya SRESID. Berdasarkan hasil uji scatterplot pada Gambar 2 terlihat bahwa titik-titik menyebar secara acak serta tersebar baik di atas maupun di bawah angka 0 pada sumbu $\mathrm{Y}$ hal ini dapat disimpulkan bahwa tidak terjadi heterokedastisitas pada model regresi

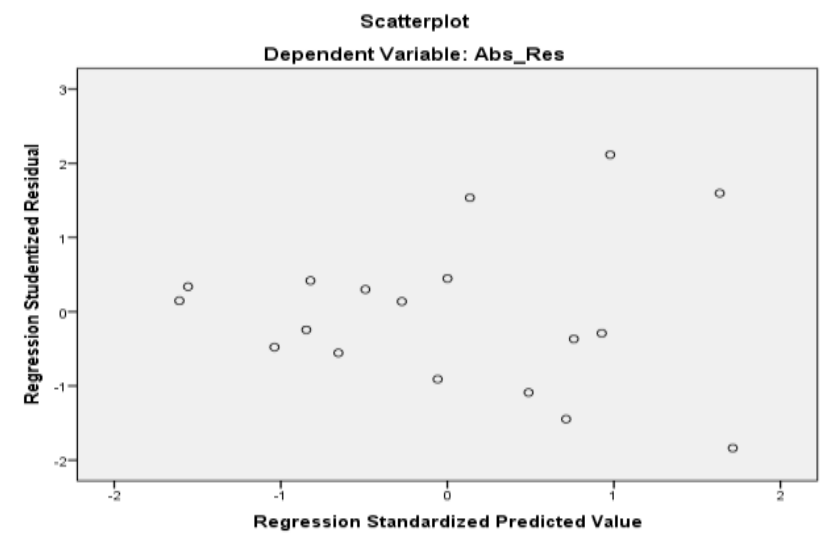

Gambar 2. Hasil Uji Heteroskedastisitas

Uji multikolinearitas bertujuan untuk menguji apakah dalam model regresi ditemukan adanya korelasi antar variabel independen. Model regresi yang baik seharusnya tidak terjadi korelasi antara variabel independen. Hasil uji multikolinearitas dapat dilihat pada Tabel 2 dengan hasil uji untuk variabel indikator ekonomi memiliki nilai tolerance sebesar 0.765 dan VIF sebesar 1.307, indikator lingkungan memiliki nilai tolerance sebesar 0.764 dan VIF sebesar 1.308, Indikator Sosial memiliki nilai tolerance sebesar 0.711 dan VIF sebesar 1.406 dapat dikatakan semua variabel tidak tejadi multikolineritas. Variabel bebas tidak terjadi multi kolineritas dapat dilihat apabila nilai tolerance diatas 0.05 dan nilai VIF dibawah 5.00.

Tabel 2. Hasil Uji Multikolineritas

\begin{tabular}{|c|c|c|c|}
\hline Model & & Tolerance & VIF \\
\hline Indikator Ekonomi & & 0.765 & 1.307 \\
Indikator Lingkungan & & 0.764 & 1.308 \\
Indikator Sosial & & 0.711 & 1.406 \\
\hline
\end{tabular}

Uji autokorelasi dilakukan untuk menghindari terjadinya korelasi antara kesalahan pengganggu pada periode $t$ dengan kesalahan pengganggu pada periode $t$ sebelumnya dalam suatu regresi linier. Dalam regresi linier disyaratkan tidak terjadi autokorelasi, jika terdapat maka dinamakan ada masalah autokorelasi. Pengujian autokorelasi dapat 
dilakukan dengan uji Durbin-Watson. Hasil uji autokorelasi dengan uji Durbin-Watson dapat dilihat pada Tabel 6 dengan nilai Durbin-Watson adalah sebesar 1.889. Sedangkan nilai dari tabel Durbin-Watson dengan signifikansi 0.05 dan jumlah data $(\mathrm{n})=18$, serta $\mathrm{k}$ $=3$ (jumlah variabel independen) diperoleh nilai dl sebesar 0.9331 dan du 1.6961. Nilai du sebesar 1.6961 lebih kecil dari Durbin-Watson (d) sebesar 1.889 dan lebih kecil dari 4$\mathrm{du}(1.6961<1.889<2.3039)$ sehingga dapat disimpulkan bahwa dalam model regresi ini tidak terjadi autokorelasi.

Tabel 3. Hasil Uji Regresi Linier Berganda

\begin{tabular}{|l|r|r|r|r|r|}
\hline \multirow{2}{*}{ Model } & \multicolumn{2}{|c|}{$\begin{array}{c}\text { Unstandardized } \\
\text { Coefficients }\end{array}$} & $\begin{array}{c}\text { Standardized } \\
\text { Coefficients }\end{array}$ & & \\
\cline { 2 - 4 } & \multicolumn{1}{|c|}{$\mathrm{B}$} & Std. Error & \multicolumn{1}{c|}{ Beta } & \multicolumn{1}{c|}{$\mathrm{t}$} & \multicolumn{1}{c|}{ Sig. } \\
\hline (Constant) & -1.666 & 1.422 & & -1.172 & 0.261 \\
Indikator Ekonomi & 1.111 & 1.366 & 0.169 & 0.813 & 0.430 \\
Indikator Lingkungan & -4.305 & 1.505 & -0.594 & -2.860 & 0.013 \\
Indikator Sosial & 6.866 & 2.092 & 0.707 & 3.282 & 0.005 \\
\hline
\end{tabular}

Berdasarkan Tabel 3 hasil analisis regresi linear berganda di atas dapat diperoleh persamaan regresi dengan rumus yaitu sebagai berikut :

$\mathrm{Y}=\alpha+\beta 1 \mathrm{X} 1+\beta 2 \mathrm{X} 2+\beta 3 \mathrm{X} 3+\varepsilon$

$Y=-1.666+1.111 X 1-4.305 X 2+6.866 X 3+\varepsilon$

Dari hasil analisis regresi liniear berganda pada Tabel 3 dapat dilihat variabel yang memiliki tanda negatif hanya indikator lingkungan, sedangkan indikator ekonomi dan indikator sosial memiliki arah yang positif. Tanda ini menunjukkan arah dari pengaruh variabel bebas terhadap variabel terikat. Dari koefisien regresi dapat diketahui bahwa indikator sosial dengan nilai paling besar (6.866), sehingga indikator sosial merupakan variabel yang paling besar pengaruhnya terhadap nilai perusahaan.

Pengujian hipotesis menggunakan uji $t$ dapat dilihat pada Tabel 3 dengan melihat hasil t-hitung atau nilai signifikan dari variabel bebas. Ho diterima bila t-hitung $\leq \mathrm{t}$-tabel atau nilai signifikan $\geq 0.05$. Ho diterima memiliki arti bahwa indikator ekonomi/lingkungan/sosial secara parsial tidak memiliki pengaruh terhadap varibel terikat. Nilai $\mathrm{t}-(14,0.05)$ yang diperoleh dari table $\mathrm{t}$ untuk model dalam penelitian ini adalah 1.761. Hasil uji t untuk model penelitian ini dapat dilihat pada Tabel 4.

Tabel 4. Hasil Uji t

\begin{tabular}{|l|c|c|c|}
\hline \multicolumn{1}{|c|}{ Variabel } & t-tabel & t-hitung & Keputusan \\
\hline Indikator Ekonomi (X1) & 1.761 & $|0.813|$ & Ho diterima \\
Indikator Lingkungan (X2) & 1.761 & $|-2.860|$ & Ho ditolak \\
Indikator Sosial (X3) & 1.761 & $|3.282|$ & Ho ditolak \\
\hline
\end{tabular}

Berdasarkan hasil uji-t maka indikator lingkungan dan indikator sosial yang memiliki pengaruh terhadap nilai perusahaan pada perusahaan BUMN sektor pertambangan. Indikator lingkungan memiliki pengaruh dengan tanda negatif yang berarti setiap kenaikan indikator lingkungan sebesar 4.305 satuan maka akan terjadi penurunan nilai perusahaan sebesar satu satuan. Sedangkan indikator sosial memiliki pengaruh dengan tanda positif yang berarti setiap kenaikan indikator sosial sebesar 1.111 satuan maka akan terjadi peningkatan nilai perusahaan sebesar satu satuan. Indikator ekonomi tidak berpengaruh terhadap nilai perusahaan, hal ini menunjukkan bahwa investor tidak cukup yakin dengan informasi sukarela seperti pengungkapan CSR yang diungkapkan oleh manajemen, sehingga dapat ditarik kesimpulan bahwa investor tidak menggunakan informasi tersebut sebagai dasar untuk decision making. Hal ini disebabkan karena perusahaan BUMN pada sektor pertambangan pastinya akan memiliki keuntungan/profit yang besar. Dengan demikian, indikator ekonomi tidak berpengaruh terhadap nilai perusahaan. Indikator lingkungan berpengaruh negatif terhadap nilai perusahaan, hal ini sesuai dengan sifat perusahaan pertambangan yang sangat erat hubungannya dengan
Firm Value and Corporate Social Responsibility 195 
Firm Value and Corporate Social Responsibility

196 sumber daya alam dan lingkungan. Perusahaan pertambangan yang sifatnya melakukan perubahaan struktur terhadap alam dan lingkungan dan berdampak terhadap kerusakaan lingkungan, sehingga semakin banyak penggungkapan indikator lingkungan akan menyebabkan penurunan nilai perusahaan. Indikator sosial berpengaruh positif terhadap nilai perusahaan, hal ini menunjukkan semakin besar pengungkapan indikator perusahaan dan disajikan dalam laporan tahunan perusahaan akan membuat investor lebih tertarik terhadap perusahaan. Tertariknya investor terhadap perusahaan akan meningkatkan nilai perusahaan tersebut. Indikator sosial berpengaruh terhadap nilai perusahaan hal ini juga membuktikan keberadaan perusahaan yang dapat diterima dan bermanfaat bagi masyarakat.

Tabel 5. Hasil Uji F

\begin{tabular}{|l|r|r|r|c|c|}
\hline \multicolumn{1}{|c|}{ Model } & Sum of Squares & $d f$ & Mean Square & $F$ & Sig. \\
\cline { 1 - 4 } Regression & 0.404 & 3 & 0.135 & \multirow{2}{*}{1.275} & 0.321 \\
\cline { 1 - 3 } Residual & 1.476 & 14 & 0.105 & & \\
\cline { 1 - 4 } Total & 1.880 & 17 & & & \\
\hline
\end{tabular}

Hasil uji f dapat dilihat pada Tabel 5, Uji simultan atau uji f digunakan untuk menguji besarnya pengaruh dari seluruh variabel independen secara bersama-sama atau simultan terhadap variabel dependen. Kriteria dari uji $\mathrm{f}$ adalah Ho diterima jika nilai f-hitung $\leq \mathrm{f}$ tabel atau nilai signifikan $\geq 0.05$. Ho diterima memiliki arti CSR tidak memiliki pengaruh terhadap nilai perusahaan. Nilai f-hitung dapat dilihat pada Tabel 5 dengan nilai 1.275 dan nilai $f$ tabel $(3,14,0.05)$ diperoleh dari tabel $f$ dengan nilai 3.34. Sehingga hasil uji $f$ pada model penelitian ini menolak Ho yang memilik arti secara bersama-sama indikator ekonomi, indikator lingkungan dan indikator sosial berpengaruh terhadap nilai perusahaan. Penelitian yang dilakukan tidak sejalan dengan Benne dan Moningka (2020) yang menyebutkan bahwa CSR berpengaruh positif terhadap nilai perusahaan. Begitu juga Saputra dan Setiawan (2017) menyebutkan pengungkapan CSR pada laporan lebih luas akan meningkatkan nilai perusahaan.

Tabel 6. Hasil Uji Determinasi

\begin{tabular}{|c|c|r|r|r|r|}
\hline Model & $R$ & $\begin{array}{c}R \\
\text { Square }\end{array}$ & $\begin{array}{c}\text { Adjusted } R \\
\text { Square }\end{array}$ & $\begin{array}{c}\text { Std. Error of the } \\
\text { Estimate }\end{array}$ & $\begin{array}{l}\text { Durbin- } \\
\text { Watson }\end{array}$ \\
\hline 1 & 0.734 & 0.538 & 0.439 & 0.5399705 & 1.889 \\
\hline
\end{tabular}

Hasil uji determinasi dapat dilihat pada Tabel 6. dengan memperoleh nilai koefisien determinasi sebesar 0.439 . Nilai tersebut memiliki arti bahwa variasi perubahan variabel indikator ekonomi, indikator lingkungan dan indikator sosial dapat menjelaskan variasi perubahan nilai perusahaan sebesar 43.9 persen, sedangkan 56.1 persen dijelaskan oleh variabel lainnya yang tidak diteliti dalam penelitian ini.

\section{PENUTUP}

Hasil penelitian ini menunjukkan bahwa pengungkapan CSR dengan berdasarkan indikator GRI menunjukkan bahwa secara parsial indikator lingkungan dan indikator sosial berpengaruh terhadap nilai perusahaan BUMN sektor pertambangan, sedangkan indikator ekonomi secara parsial tidak berpengaruh terhadap nilai perusahaan BUMN sektor pertambangan. Secara simultan indikator GRI tidak berpengaruh terhadap nilai perusahaan BUMN sektor pertambangan. Dari variabel yang berpengaruh maka indikator sosial memiliki pengaruh yang paling besar terhadap nilai perusahaan BUMN sektor pertambangan. Dalam penelitian ini perubahan variasi nilai perusahaan dapat dijelaskan sebesar 43.9 persen oleh indikator GRI.

\section{DAFTAR PUSTAKA}

Benne, K., K., \& Moningka, P. (2020). Pengaruh Pengungkapan Corporate Social Responsibility Terhadap Nilai Perusahaan Dengan Profitabilitas Sebagai Variabel 
Pemoderasi Pada Perusahaan Pertambangan Yang Terdaptar di BEI. Klabat Accounting Review, 1(1), 56-70.

Amanda, A. L., Efrianti, D., \& Marpaung, B. (2019). Analisis Pengaruh Kandungan Informasi Komponen Laba Dan Rugi Terhadap Koefisien Respon Laba (Erc) Studi Empiris Pada Perusahaan Manufaktur Sektor Industri Dasar Dan Kimia Yang Terdaftar Di Bursa Efek Indonesia (Bei). Jurnal Ilmiah Manajemen Kesatuan, 7(1), 188-200.

Astrini, D., Juanda, B., \& Achsani, N. A. (2016). Impact Of Redenomination On Price, Volume, And Value Of Transaction: An Experimental Economic Approach. Bulletin of Monetary Economics and Banking, 19(2), 1-32.

Cheng, M., \& Christiawan, Y., J. (2011). Pengaruh Pengungkapan Corporate Social Responsibility terhadap Abnormal Return. Jurnal Akuntansi dan Keuangan, 13(1), 23-35.

Elkington, J. (1997). Cannibals with forks: the triple bottom line of $21^{\text {st }}$ century business, Capstone, Oxford.

Ghoul, E., 1., Sadok, O., Guedhami, C., Y., Chuck, K., \& Mishara, D., R. (2011). Does Corporate Social Responsibility Affcet the Cost of Capital. Journal of Banking \& Finance, 35 (9), 2388-2406.

Haruman, T. (2008). Pengaruh Struktur Kepemilikan Terhadap Keputusan Keuangan dan Nilai Perusahaan. Pontianak: Simposium Nasional. January-Februari, 2-17.

Kamil, A., \& Antonius, H. (2012). Pengaruh Karakteristik Perusahaan Terhadap Luas Pengungkapan Kegiatan Corporate Social Responsibility. Media Riset Akuntansi, 2(1), 2-17.

Karina, K., \& Sutarti, S. (2021). Pengaruh Ukuran Perusahaan Dan Corporate Governance Terhadap Manajemen Laba Di Industri Perbankan Indonesia. Jurnal Ilmiah Akuntansi Kesatuan, 9(1), 111-120.

Lang, L., H., P., Stulz, R., M., \& Walkling. (1989). Managerial Performance, Tobin's q, and the Gains from Successful Tender Offers. Journal of Financial Economics, 137154.

Lii, Y., \& Lee, M. (2012). Doing Right Leads to Doing Well: When the Type of CSR and Reputation Interact to Affect Consumer Evaluations of the Firm. Journal of Business Ethics, 105(1), 69-81.

Listiyani, N. (2017). Dampak Pertambangan Terhadap Lingkungan Hidup di Kalimantan Selatan dan Implikasinya Bagi Hak-hak Warga Negara. Jurnal Al'Adl, 9(1), 67-86.

Marlina, T., \& Haryanto, R. A. (2018). Pengaruh Komponen Arus Kas Dan Laba Bersih Terhadap Harga Saham Studi Empiris Pada Perusahaan Asuransi Yang Terdaftar Di Bursa Efek Indonesia Periode Tahun 2010-2014. Jurnal Ilmiah Akuntansi Kesatuan, 6(1), 85-93.

McWilliams, A., \& Siegel, D. (2001). Corporate Social Responsibility: A Theory of the Firm Perspective. The Academic of Management Review, 21(5), 117-127.

Mulyana, M., \& Sulistiono, S. (2016). Analisis Determinasi Adopsi E-Commerce Dalam Pemberdayaan Pengrajin Alas Kaki di Ciomas Kabupaten Bogor.

Rainanto, B. H., \& Fathiah, R. (2020). PKM Pembekalan Pelaku UMKM Kota Bogor Tentang Strategi Diferensiasi Dan Positioning Untuk Bertahan Dan Menang. Jurnal Abdimas Dedikasi Kesatuan, 1(2), 97-107.

Rustiarini, N., W. (2010). Pengaruh Corporate Governance Pada Hubungan Corporate Social Responsibility dan Nilai Perusahanan. Simposium Nasional Akuntansi XIII. AKPM_12.

Saputra, W., S., \& Setiawan, T. (2018). Pengaruh Corporate social responsibility disclosure (CSRD), Nilai perusahaan dan profitabilitas. Balance Vocation Accounting Journal, DOI: 10.31000/bvaj.v2i1.963.

Scholtens, B. (2008). A Note on the Interaction between Corporate Social Responsibility. Ecological Economics, 68, 46-55
Firm Value and

Corporate Social

Responsibility

197 
Firm Value and Corporate Social Responsibility
Stella, L. A., \& Puspitasari, R. (2020, May). Analysis of Bank Rating with RGEC Method Case Study at PT Bank Mandiri (Persero) Tbk for the Period 2013-2017. In 2nd International Seminar on Business, Economics, Social Science and Technology (ISBEST 2019) (pp. 240-245). Atlantis Press.

Sujana. (2017). Pengaruh CSR dan Kepemilikan Managerial terhadap Nilai Perusahaan dengan Profitabilitas sebagai Variabel Moderating. Universitas Pendidikan Ganesha, $7(1)$.

Sukamto, A., \& Nurachmad, E. (2020). Pelatihan Persiapan Studi Lanjut Di Jurusan Teknologi Informasi. Jurnal Abdimas, 4(1), 61-70.

SYAFITRI, H. W., Nurendah, Y., \& Mashadi, M. (2013). STRATEGI PELAYANAN PADA PENJUALAN SEPEDA MOTOR HONDA PADA PT. SANPRIMA SENTOSA BOGOR (Doctoral dissertation, Institut Bisnis dan Informatika Kesatuan).

Tobin's, J. (1969). A General Equilibrium Approach to Monetary Theory. Journal of Money, Credit and Banking, 12- 29.

Wahyudi, H., S., \& Sukmasari, M., P. (2014). Teknologi dan Kehidupan Masyarakat. Jurnal Analisis Sosiologi, 3(1), 13-24.

Walter, B., L. (2014). Corporate Social Responsibility Communication: Towards a Phase Model of Strategic Planning. Communicating Corporate Social Responsibility: Perspectives and Practice. DOI: 10.1108/S2043-9059(2014)0000006022. 